\title{
Article \\ A Novel Truncating Mutation in HOMER2 Causes Nonsyndromic Progressive DFNA68 Hearing Loss in a Spanish Family
}

\author{
María Lachgar ${ }^{1,2,+}+\mathbb{D}$, Matías Morín ${ }^{1,2,+} \mathbb{D}$, Manuela Villamar ${ }^{1,2}$, Ignacio del Castillo ${ }^{1,2}$ \\ and Miguel Ángel Moreno-Pelayo 1,2,*(D) \\ 1 Servicio de Genética, Hospital Universitario Ramón y Cajal, IRYCIS, Carretera de Colmenar km 9.100, \\ 28034 Madrid, Spain; maria.lachgar95@gmail.com (M.L.); matmorinro@yahoo.es (M.M.); \\ taugen.hrc@salud.madrid.org (M.V.); delcastilloi@hotmail.com (I.d.C.) \\ 2 Centro de Investigación Biomédica en Red de Enfermedades Raras (CIBERER), 28034 Madrid, Spain \\ * Correspondence: mmorenop@salud.madrid.org \\ + These authors have contributed equally to this work.
}

check for updates

Citation: Lachgar, M.; Morín, M.; Villamar, M.; del Castillo, I.; Moreno-Pelayo, M.Á. A Novel Truncating Mutation in HOMER2 Causes Nonsyndromic Progressive DFNA68 Hearing Loss in a Spanish Family. Genes 2021, 12, 411. https:// doi.org/10.3390/genes12030411

Academic Editors: Santiago Rodriguez and Laura Crisponi

Received: 20 December 2020

Accepted: 9 March 2021

Published: 12 March 2021

Publisher's Note: MDPI stays neutral with regard to jurisdictional claims in published maps and institutional affiliations.

Copyright: (c) 2021 by the authors. Licensee MDPI, Basel, Switzerland. This article is an open access article distributed under the terms and conditions of the Creative Commons Attribution (CC BY) license (https:/ / creativecommons.org/licenses/by/ $4.0 /)$.

\begin{abstract}
Nonsyndromic hereditary hearing loss is a common sensory defect in humans that is clinically and genetically highly heterogeneous. So far, 122 genes have been associated with this disorder and 50 of them have been linked to autosomal dominant (DFNA) forms like DFNA68, a rare subtype of hearing impairment caused by disruption of a stereociliary scaffolding protein (HOMER2) that is essential for normal hearing in humans and mice. In this study, we report a novel HOMER2 variant (c.832_836delCCTCA) identified in a Spanish family by using a custom NGS targeted gene panel (OTO-NGS-v2). This frameshift mutation produces a premature stop codon that may lead in the absence of NMD to a shorter variant (p.Pro278Alafs*10) that truncates HOMER2 at the CDC42 binding domain (CBD) of the coiled-coil structure, a region that is essential for protein multimerization and HOMER2-CDC42 interaction. c.832_836delCCTCA mutation is placed close to the previously identified c.840_840dup mutation found in a Chinese family that truncates the protein (p.Met281Hisfs*9) at the CBD. Functional assessment of the Chinese mutant revealed decreased protein stability, reduced ability to multimerize, and altered distribution pattern in transfected cells when compared with wild-type HOMER2. Interestingly, the Spanish and Chinese frameshift mutations might exert a similar effect at the protein level, leading to truncated mutants with the same $\mathrm{Ct}$ aberrant protein tail, thus suggesting that they can share a common mechanism of pathogenesis. Indeed, age-matched patients in both families display quite similar hearing loss phenotypes consisting of early-onset, moderate-to-profound progressive hearing loss. In summary, we have identified the third variant in HOMER2, which is the first one identified in the Spanish population, thus contributing to expanding the mutational spectrum of this gene in other populations, and also to clarifying the genotype-phenotype correlations of DFNA68 hearing loss.
\end{abstract}

Keywords: hereditary hearing loss; next-generation sequencing; custom panel; HOMER2; CDC42

\section{Introduction}

Hearing loss is the most common sensory deficit in humans, affecting around 1 in 1000 newborns. Its prevalence increases with the age up to $6-8 \%$ in the adult population, having a strong impact on the individual's social isolation [1]. Genetic causes account for 50-60\% of newborn hearing loss, $30 \%$ of which are nonsyndromic forms of deafness [2]. The genetic etiology of hearing impairment is highly heterogeneous. Up to date, 160 nonsyndromic sensorineural hearing loss (NSSNHL) loci have been mapped, of which 122 genes have been identified [3]. Sixty-seven of these loci and 50 of these genes are associated with autosomal dominant NSSNHL, being, in most cases, rare forms of post-lingual and progressive hereditary hearing impairment.

Autosomal dominant NSSNHL-linked genes encode proteins with a wide variety of functions [4], such as cytoskeleton proteins (ACTG1, DIAPH1, PLS1), adhesion proteins (GJB2, 
GJB3, GJB6, TJP2), motor proteins (myosins), scaffolding proteins (HOMER2), extracellular matrix proteins (TECTA, COL11A2), proteins involved in ion homeostasis, such as ionic channels (KCNQ4), transcription factors (EYA4, POU4F3), and even a microRNA (MIR96) [5].

The HOMER2 gene maps to chromosome 15q24.3 [6] within the DFNA68 critical interval and consists of nine exons. Two human transcript variants have been described (NM_004839.4 and NM_199330.3) as encoding the short isoform 1 (NP_004830.2, 343aa) and the long isoform 2 (NP_955362.1, 354aa) of HOMER2, respectively. HOMER2 belongs to a protein family encompassing three members: HOMER1 (MIM604798), HOMER2/CUPIDIN (MIM604799), and HOMER3 (MIM604800). Like HOMER2, members 1 and 3 of the family have long and short isoforms due to alternative splicing [7]. HOMER family members are scaffolding proteins that play a key role in $\mathrm{Ca}^{2+}$ signaling [8-10], mostly at the PostSynaptic-Densities (PSD) [11], where they interact with G-protein coupled metabotropic glutamate receptors (mGluRs) [12] and regulate excitatory signal transduction and receptor plasticity [7]. In their structure, HOMER proteins present a conserved N-terminal domain known as Enabled/vasodilator-stimulated phosphoprotein (Ena/VASP) homology 1 (EVH1) domain $[7,13]$ that binds to proline-rich sequences (i.e. Pro-Pro- $x-x-P h e$, Pro- $x-x-$ Phe or Leu-Pro-Ser-Ser-Pro, where $x$ represents any amino acid) and a C-terminal domain that consists of a coiled-coil (CC) structure that includes a CDC42 binding domain (CBD) and two Leucine Zipper (LZA and LZB) motifs $[7,14]$. This C-terminal fragment mediates self-association with other Homer family members [7] and the interaction with the small GTPase CDC42 [15] through its CBD.

In mice, Homer 2 is widespread in the developing and maturing brain [16]. Recently, a study has shown that this gene is also expressed in a wide variety of developing tissues, including tooth, eye, cochlea, salivary glands, olfactory and respiratory mucosae, bone, and taste buds, being highly concentrated at puncta [17]. HOMER2 exhibits overlapping distribution patterns with HOMER1 and HOMER3, although they are distributed at distinct subcellular domains in several cell types $[17,18]$. Within the inner ear, HOMER2 is expressed in the stria vascularis, the Reissner's membrane, and the inner and outer hair cells of the organ of Corti, especially in the stereocilia but also in perinuclear puncta and the cytoplasm $[17,18]$. Mild expression is observed in the vascular endothelium of the cochlea and the spiral ganglion [12]. Mice homozygous for the targeted deletion of Homer2 display early-onset rapidly progressive hearing loss [18].

HOMER2 was firstly associated with hearing loss by Azaiez et al. [18] who identified a heterozygous missense variant (p.Arg196Pro) in a European ascent family. A second mutation in HOMER2 (c.840_840dup; p.Met281Hisfs*9) was identified by Lu et al. [19] by Whole Exome Sequencing (WES) in a Chinese family segregating with hearing loss. Here, we present a third variant in HOMER2 (c.832_836delCCTCA, p.Pro278Alafs*10, NM_199330.3). This variant represents the second truncating mutation that affects the CBD and lead, as in the previous two families, to post-lingual and progressive hearing loss. This mutation is the first one identified in the Spanish population, thus increasing the mutational spectrum of this gene associated with DFNA68, a rare form of autosomal dominant nonsyndromic progressive hearing loss.

\section{Patients and Methods}

\subsection{Patients Selection}

Patients and healthy relatives of family S1074 (Figure 1A) were recruited from the University Hospital Ramón y Cajal (Madrid-Spain). Clinical history ruled out environmental factors as the cause of the hearing loss in the probands, and physical examination did not reveal any evidence of syndromic features. No other clinically significant manifestations, including balance or visual problems, were reported by any of the affected individuals. The hearing level was evaluated through pure tone audiometry. Air conduction thresholds were determined at frequencies ranging from 250 to $8000 \mathrm{~Hz}$ according to standard protocols. This study was designed in compliance with the tenets of the Helsinki Declaration, and patient enrolment was approved by the ethics committee and the human research Institu- 
tional Review Boards of Hospital Ramón y Cajal (IRB number: 288-17). All participants of the family approved of the study and signed the Informed Consent.

\subsection{Sample Collection}

A peripheral blood sample from each subject of the family S1074 enrolled in the study was collected by venipuncture in $5 \mathrm{mM}$ EDTA tubes and genomic DNA was extracted using Chemagen MSM I (Magnetic Separation Module I, PerkinElmer, Massachusetts, MA, USA) according to the manufacturer's instructions. DNA was quantified by the fluorometric method Qubit 3.0 Fluorometer (Thermo Fisher Scientific, Massachusetts, MA, USA).

\subsection{Targeted Next-Generation Sequencing}

The index case of the family (II:2) was subjected for the genetic screening for causative hearing-loss mutations by using a custom gene panel, OTO-NGS-v2, designed in our laboratory [20]. As the causative mutation was identified following this approach, whole exome sequencing (WES) on the individual II:2 was not further performed. OTO-NGS-v2 is based on IDT probes capture system that included 117 genes associated with NSSNHL. Sequencing of captured enriched-libraries was done on the Illumina MiSeq (Illumina, Inc., San Diego, CA, USA). The sequence data were mapped against the human genome sequence (build GRCh37/hg19), and data analysis was performed using the Sophia Genetics' software that enables the single nucleotide variations (SNVs) and the copy number variation $(\mathrm{CNV})$ analysis of the targeted exonic sequences. Variant prioritization was carried out using a custom filtering strategy [20].

\subsection{Sanger Sequencing}

The c.832_836delCCTCA mutation in exon 8 of HOMER2 [NM_199330.3, long transcript] was verified by Sanger sequencing (Figure 1B). Briefly, a forward and a reverse oligonucleotide were designed for amplification of exon 8 (F-oligo 5'-CGTGCACACATTGGTGATTT-3' $^{\prime}$ and R-oligo 5'-AAGCAGGAAAATGAGTACCATGA-3') followed by Sanger sequencing using the BigDye ${ }^{\mathrm{TM}}$ Terminator v3.1 Cycle Sequencing Kit (Applied Biosystems, Foster City, CA, USA) according to manufacturer's directions in an ABI 3730S sequencer (Perkin Elmer, Waltham, MA, USA). The specificity of the primers designed for the amplification and Sanger sequencing of exon 8 of HOMER2 was confirmed by BlastN (https:/ /blast.ncbi.nlm. nih.gov/; access date: 9 March 2021). We obtained a unique blast hit for the amplimer at chromosome 15 (NC_000015.10; coordinates 82,851,291 to 82,851,310) within the HOMER2 genomic region. Segregation analysis was performed by checking the presence of the c.832_836delCCTCA mutation in all the affected and unaffected family members.

\section{Results}

\subsection{Clinical Description of the Family}

The clinical history and audiological assessments of the affected members reported a post-lingual bilateral progressive hearing loss consistent with an autosomal dominant inheritance pattern (Figure 1A). Individuals II:2 (8 years old) and II:3 (15 years old) exhibited moderate hearing loss with greater impact on the high frequencies (downsloping profile). Their mother (patient I:2, 39 years old) showed a more severe phenotype, displaying profound hearing loss at frequencies higher than $2000 \mathrm{~Hz}$. The father (I:1, 44 years old) and his healthy son (II:1, 11 years old) showed normal hearing thresholds (Figure 1C) at the time of the study. 
A

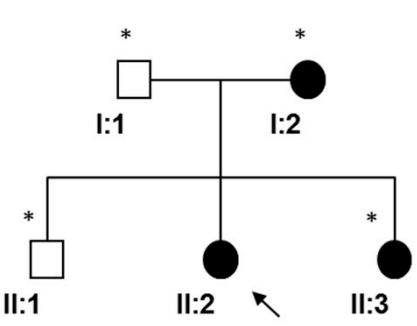

B

AT CA T AC C T CAG C T CAT G T CA G AG T

Ile Ile Pro GIn Leu Met Ser Glu

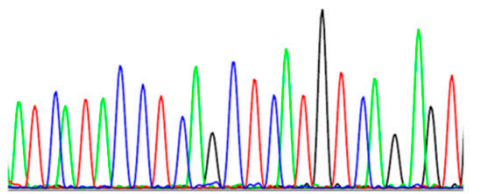

c.832 836delCCTCA
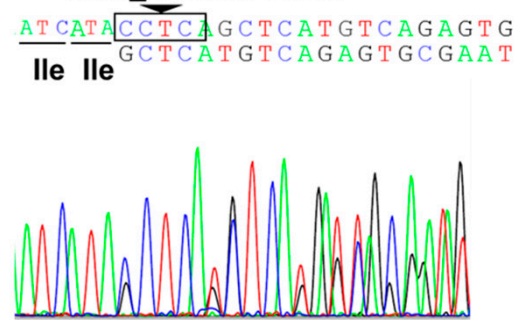

C

D
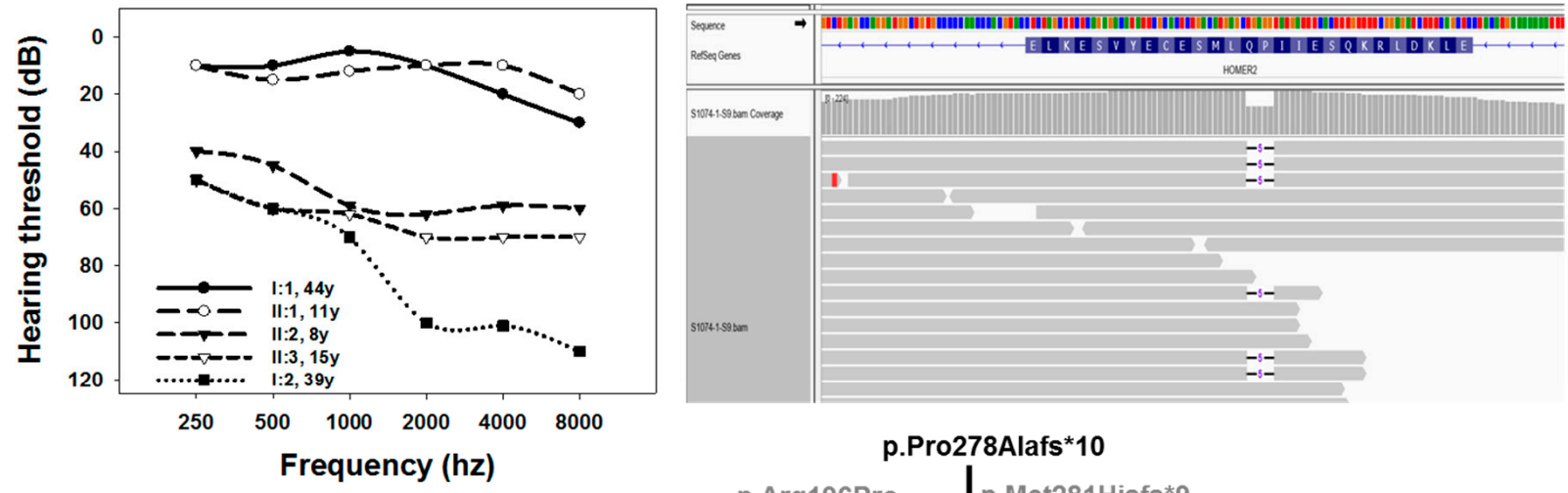

p.Pro278Alafs ${ }^{*} 10$

E

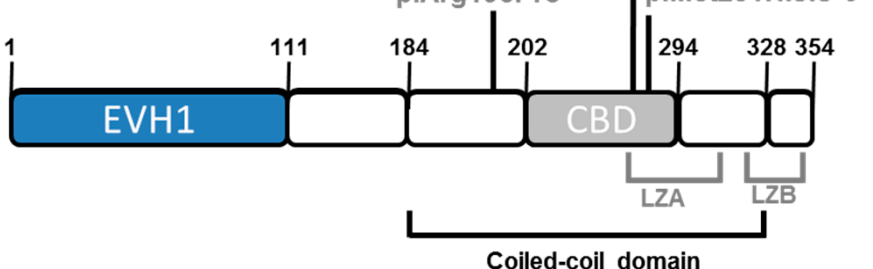

Figure 1. (A) Pedigree of the S1074 family indicating the segregation of c.832_836delCCTCA mutation in HOMER2. Black symbols indicate affected patients (carrying the mutation in heterozygosis), and white symbols correspond to normal hearing individuals (wild-type for the mutation studied). The subject pointed with an arrow is the index case (studied by OTO-NGS-v2 panel), and the ones marked with an asterisk were analysed by Sanger sequencing for segregation analysis. (B) Electropherograms corresponding to the wild-type (left) and mutant (right) sequences of a normal hearing and an affected individual, respectively. (C) Audiograms of the S1074 family. The data represented correspond to the average of the audiometric thresholds in both ears. (D) Integrative Genomics Viewer (IGV) (Broad Institute) screenshot showing the genomic region corresponding to the c.832_836delCCTCA mutation of HOMER2 and the translated protein stretch corresponding to exon 8 in the reverse orientation (NP_955362.1, HOMER2 long isoform, amino acid range 292-266), as HOMER2 is transcribed by using the DNA negative strand. (E) Schematic representation of the structure of HOMER2 long isoform (NP_955362.1). The different domains [7,14,21] and the mutations identified so far associated with hearing loss (in grey) are shown. The mutation identified in this work is shown in black. EVH1 (1-111 aa): Enabled/vasodilator-stimulated phosphoprotein (Ena/VASP) homology 1; Coiled-coil domain (184-328 aa); CBD (202-294 aa): CDC42-binding domain. LZA (249-307 aa): Leucine Zipper-A; LZB (322-350 aa): Leucine Zipper-B.

\subsection{Genetic Study}

By using the OTO-NGS-v2 panel and Sophia DMM software 338 heterozygous genetic variants were retained in the index case (II:2) of the family, 10 of which were classified as potentially pathogenic in HOMER2, MYO7A, TMPRSS3, COL11A2, GPSM2, BDP1, EPS8, EPS8L2, OSBPL2, and PCDH15 genes, respectively (Table 1). During the tertiary analysis, 9 variants were discarded. Two of them showed high population frequencies in the Genome Aggregation Database (GnomAD) and were classified as benign variants in ClinVar (MYO7A, COL11A2). The other 6 variants were associated with recessive forms of deafness (TMPRSS3, GPSM2, BDP1, EPS8, EPS8L2, and PCDH15). The variant c.747A >G (rs1309059934) in OSBPL2 (DFNA67) was classified by Sophia DMM as poten- 
tially pathogenic. However, it resulted in a synonymous protein change (p.Arg249Arg) that was classified as likely benign (BP4, BP7, and PM2) according to the American College of Medical Genetics and Genomics (ACMG) guidelines [22,23]. Furthermore, we confirmed by Sanger sequencing that this mutation did not segregate with the hearing loss in the family as it was detected in the normal-hearing subject II:I.

Finally, a novel mutation in HOMER2 gene, c.832_836delCCTCA, was identified in the propositus of the $\mathrm{S} 1074$ family (patient II:2). This variant was identified at exon 8 of HOMER2 and is supposed to alter the two transcript variants with known reported expression (NM_004839.4, short transcript, and NM_199330.3, long transcript). The variant leads to a frameshift generating a premature stop codon that in the absence of nonsensemediated decay (NMD) may produce a truncated HOMER2 protein ( $\mathrm{p}$. Pro278Alafs*10). This mutation was classified as pathogenic (PVS1, PM2 and PP3) according to the ACMG guidelines [22,23]. The variant was not present in the GnomAD [24], in the Collaborative Spanish Variant Server-CSVS database [25] nor in the Deafness Variation Database (DVD, http:/ / deafnessvariationdatabase.org/; access date: 9 March 2021;) [26,27]. Additionally, we confirmed by Sanger sequencing (Figure 1B) it segregated with the hearing loss in the family. The novel HOMER2 variant c.832_836delCCTCA has been deposited in ClinVar (accession\# SCV001499845). Comparison of the genetic and clinical data of the S1074 family with previously reported cases is made in Table 2.

\section{Discussion}

Hearing loss caused by HOMER2 mutations is an extremely rare disorder. In this study, we have used OTO-NGS-v2, a custom targeted NGS panel, for the identification of a novel mutation (c.832_836delCCTCA; p.Pro278Alafs*10) in this gene linked to DFNA68 hearing loss. To date, only two different mutations in HOMER2 have been documented to cause hearing loss. The first mutation was a missense substitution (c.587G >C; p.Arg196Pro; NM_199330.3) that affects a highly conserved residue in the coiled-coil (CC) structure, a region that is required for homo/hetero-multimerization to form tetrameric hubs (in which the CC domains align in a parallel fashion) and for interaction through the CBD with Rho family GTPase proteins like CDC42, a GTPase that mediates actin-turnover [28] and is responsible for planar polarity establishment in hair cells [29,30]. Functional assessment of the p.Arg196Pro in zebrafish strongly suggests that this mutation exerts its effect through a dominant-negative mechanism on wild-type protein by either inhibiting multimerization or competing for partner proteins [18]. The second mutation, c.840_840dup, p.Met281Hisfs*9 (NM_199330.3) was identified in a Chinese family with symmetric ADSNHL [19]. This frameshift variant at the CDC42-binding domain leads to the generation of a premature stop codon supposed to produce a truncated HOMER2 protein of 288 amino acids, with an aberrant protein tail of 8 amino acids from position 281 onwards.

In this work, we have identified a novel frameshift mutation, c.832_836delCCTCA, p.Pro278Alafs $* 10$ in HOMER2 that represents the second truncating mutation identified in the CDC42-binding domain. The Spanish mutation also creates a premature stop codon that may lead to generate a truncated shorter protein of 286 amino acids with an aberrant tail of 9 amino acids from position 278, thus lacking the canonical C-terminal end. Interestingly, the alignment of both truncated proteins revealed an identical sequence of the last 8 amino acids of the aberrant tails (Figure 2). 
Table 1. Genetic variants with potential pathogenicity identified by SOPHIA DDM software in the index case (II:2) of family S1074.

\begin{tabular}{|c|c|c|c|c|c|c|c|c|c|}
\hline $\begin{array}{c}\text { Gene } \\
\text { Transcript }\end{array}$ & Exon & $\begin{array}{c}\text { c.DNA and } \\
\text { Protein Alteration }\end{array}$ & $\begin{array}{c}\text { Variant Fraction } \\
\text { Coverage (Ref/Alt) }\end{array}$ & Coding Consequence & $\begin{array}{l}\text { Pathogenicity } \\
\text { Prediction by } \\
\text { SOPHIA DDM }\end{array}$ & ACMG & $\begin{array}{l}\text { ClinVar } \\
\text { Rating }\end{array}$ & GnomAD & Locus \\
\hline $\begin{array}{c}\text { HOMER2 } \\
\text { NM_199330 }\end{array}$ & 8 & $\begin{array}{l}\text { c.832_836delCCTCA } \\
\text { p.Pro278Alafs*10 }\end{array}$ & $\begin{array}{l}34.98 \% \\
(145 / 78) \\
\end{array}$ & frameshift & Highly Pathogenic & $\begin{array}{c}\text { Pathogenic } \\
\text { (PVS1, PM2, PP3) }\end{array}$ & - & 0 & DFNA68 \\
\hline $\begin{array}{c}\text { MYO7A } \\
\text { NM_001127179 } \\
\end{array}$ & 27 & $\begin{array}{c}\text { c.3515_3536del } \\
\text { p.Gly1172*1179del }\end{array}$ & $\begin{array}{c}49.0 \% \\
(582 / 306) \\
\end{array}$ & No-stop & Highly Pathogenic & $\begin{array}{c}\text { Benign } \\
\text { (PVS1, BA1, BS2, BP6) } \\
\end{array}$ & $\begin{array}{c}\text { Benign } \\
\text { rs111033223 } \\
\end{array}$ & 0.391 & $\begin{array}{c}\text { DFNA11 } \\
\text { DFNB2 } \\
\end{array}$ \\
\hline $\begin{array}{c}\text { TMPRSS3 } \\
\text { NM_001256317 } \\
\end{array}$ & 8 & c.617-3_617-2dupTA p.? & $\begin{array}{c}46.73 \% \\
(421 / 372)\end{array}$ & $\begin{array}{c}\text { Splice } \\
\text { acceptor }\end{array}$ & Highly Pathogenic & (PVS1, PP3, BA1, BP6) & $\begin{array}{c}\text { Benign } \\
\text { rs34966432 }\end{array}$ & 0.118 & $\begin{array}{c}\text { DFNB8 } \\
\text { DFNB10 }\end{array}$ \\
\hline $\begin{array}{c}\text { COL11A2 } \\
\text { NM_080679 }\end{array}$ & 32 & c. $2307+3 \mathrm{G}>\mathrm{A} \mathrm{p} . ?$ & $\begin{array}{c}50.43 \% \\
(402 / 409) \\
\end{array}$ & splice_donor_+3 & $\begin{array}{l}\text { Potentially } \\
\text { Pathogenic }\end{array}$ & $\begin{array}{c}\text { Benign } \\
\text { (BA1, BS2) }\end{array}$ & $\begin{array}{l}\text { Benign } \\
\text { rs970901 }\end{array}$ & 0.601 & $\begin{array}{l}\text { DFNA13 } \\
\text { DFNB53 } \\
\end{array}$ \\
\hline $\begin{array}{c}\text { GPSM2 } \\
\text { NM_013296 }\end{array}$ & 13 & $\begin{array}{c}\text { c.1572_1574delTTC } \\
\text { p.Ser525del }\end{array}$ & $\begin{array}{c}48.55 \% \\
(278 / 267)\end{array}$ & inframe_3 & $\begin{array}{l}\text { Potentially } \\
\text { Pathogenic }\end{array}$ & Benign(PP3, BA1, BP3, BP6) & $\begin{array}{c}\text { Benign } \\
\text { rs35029887 }\end{array}$ & 0.291 & DFNB82 \\
\hline $\begin{array}{c}\text { BDP1 } \\
\text { NM_018429 }\end{array}$ & 23 & $\begin{array}{c}\text { c.5068G>C } \\
\text { p.Gly1690Arg }\end{array}$ & $\begin{array}{c}44.54 \% \\
(335 / 269)\end{array}$ & missense & $\begin{array}{l}\text { Potentially } \\
\text { Pathogenic }\end{array}$ & $\begin{array}{l}\text { Likely Benign } \\
\text { (PM2, BP1, BP4) }\end{array}$ & $\begin{array}{c}- \\
\text { rs193135814 }\end{array}$ & $7.48 \times 10^{-5}$ & DFNB112 \\
\hline $\begin{array}{c}\text { EPS8 } \\
\text { NM_004447 }\end{array}$ & 20 & $\begin{array}{l}\text { c.2230G }>\text { A } \\
\text { p.Val744Ile }\end{array}$ & $\begin{array}{c}44.34 \% \\
(359 / 286)\end{array}$ & missense & $\begin{array}{l}\text { Potentially } \\
\text { Pathogenic }\end{array}$ & $\begin{array}{c}\text { Benign } \\
\text { (BS1, BS2, BP1, BP6) } \\
\end{array}$ & $\begin{array}{l}\text { Likely Benign } \\
\text { rs77967764 }\end{array}$ & $2.06 \times 10^{-3}$ & DFNB102 \\
\hline $\begin{array}{c}\text { EPS8L2 } \\
\text { NM_022772 }\end{array}$ & 9 & $\begin{array}{c}\text { c.710G }>\mathrm{T} \\
\text { p.Arg237Leu }\end{array}$ & $\begin{array}{c}50.22 \% \\
(560 / 565)\end{array}$ & missense & $\begin{array}{l}\text { Potentially } \\
\text { Pathogenic }\end{array}$ & $\begin{array}{c}\text { VUS } \\
\text { (PM2, BP4) }\end{array}$ & - & $7.1 \times 10^{-6}$ & DFNB106 \\
\hline $\begin{array}{c}\text { OSBPL2 } \\
\text { NM_014835 } \\
\end{array}$ & 9 & $\begin{array}{c}\text { c.747A }>\mathrm{G} \\
\text { p.Arg249Arg }\end{array}$ & $\begin{array}{c}51.09 \% \\
(157 / 164) \\
\end{array}$ & synonymous & $\begin{array}{l}\text { Potentially } \\
\text { Pathogenic }\end{array}$ & $\begin{array}{c}\text { Likely Benign } \\
\text { (BP4, BP7, PM2) } \\
\end{array}$ & $\begin{array}{c}- \\
\text { rs1309059934 }\end{array}$ & 0 & DFNA67 \\
\hline
\end{tabular}

Table 2. Clinical data and classification of the different variants described in HOMER2 causing hearing loss.

\begin{tabular}{|c|c|c|c|c|c|c|c|c|c|c|c|c|c|}
\hline DNA Change & Protein Change & Exon & Origin & Phenotype & $\begin{array}{l}\text { Detection } \\
\text { Decade }\end{array}$ & Degree & $\begin{array}{l}\text { Audiogram } \\
\text { Profile }\end{array}$ & ACMG Classification & $\begin{array}{l}\text { Number of Scores Supporting } \\
\text { Pathogenicity Pathogenicity }\end{array}$ & DVD & $\begin{array}{c}\text { CSVS } \\
\text { Allele Freq }\end{array}$ & $\begin{array}{l}\text { GnomAD } \\
\text { Allele Freq. }\end{array}$ & References \\
\hline c. $587 \mathrm{G}>\mathrm{C}$ & p.Arg196Pro & 6 & $\begin{array}{l}\text { European } \\
\text { descent }\end{array}$ & SNHL & 1st & $\begin{array}{l}\text { Mild- } \\
\text { profound }\end{array}$ & $\begin{array}{l}\text { Down- } \\
\text { sloping }\end{array}$ & $\begin{array}{l}\text { Uncertain significance } \\
\text { (PM2, PP3, PP5, BP1) }\end{array}$ & $20 / 22$ & N.A & 0 & 0 & $\begin{array}{l}\text { Azaiez et al. } \\
2015\end{array}$ \\
\hline c.840_840dup & p.(Met281Hisfs*9) & 8 & Chinese & SNHL & 1 st & $\begin{array}{l}\text { Moderate- } \\
\text { profound }\end{array}$ & $\begin{array}{l}\text { Down- } \\
\text { sloping }\end{array}$ & $\begin{array}{c}\text { Pathogenic } \\
\text { (PVS1, PM2, PP3, PP5) }\end{array}$ & N.A & N.A & 0 & 0 & Lu et al. 2018 \\
\hline c.832_836delCCTCA & p.(Pro278Alafs*10) & 8 & Spanish & SNHL & 1 st & $\begin{array}{l}\text { Moderate- } \\
\text { profound }\end{array}$ & $\begin{array}{l}\text { Down- } \\
\text { sloping }\end{array}$ & $\begin{array}{c}\text { Pathogenic } \\
\text { (PVS1, PM2, PP3) }\end{array}$ & N.A & N.A & 0 & 0 & This work \\
\hline
\end{tabular}

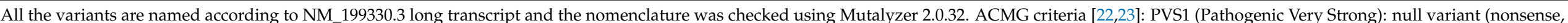

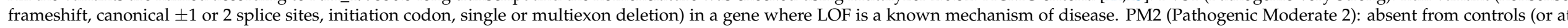

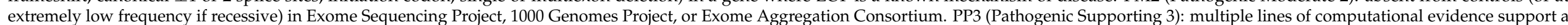

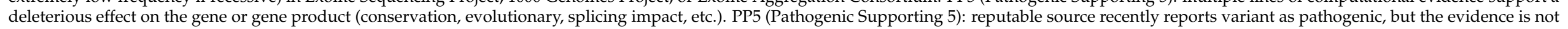

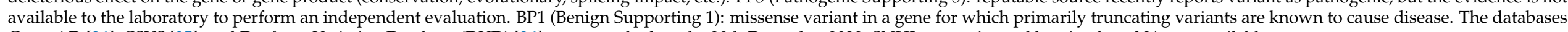
GnomAD [24], CSVS [25], and Deafness Variation Database (DVD) [26] were searched on the 20th December 2020. SNHL: sensorineural hearing loss, NA: not available 
Wt human HOMER2

p.Met281Hisfs*9

p.Pro278Alafs*10
266 ELKDLRKQSEIIPQLMSECEYVSEKLE

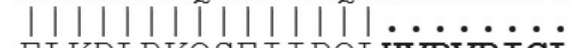
266 ELKDLRKQSEIIPQLHVRVRICL

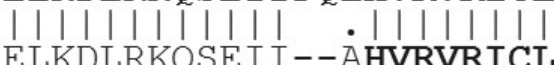

292

288

286

Figure 2. Alignment of the wild-type protein fragment encoded by exon 8 of HOMER2 long isoform (NP_955362.1) and the truncating mutations in the CDC42-binding domain (CBD) identified in the Chinese (p.Met281Hisfs*9) and Spanish (p.Pro278Alafs*10) families. The amino acid sequence shared between both aberrant protein tails is shown in bold face.

Based on the similar effect that the two different frameshift mutations may cause at the protein level, both supposed to truncate the protein at the $\mathrm{CDB}$ and resulting in the same aberrant tail, it might be reasonable to suggest that the Chinese and Spanish mutations may share a similar mechanism of pathogenesis. Lu et al. demonstrated that the p.Met281Hisfs $* 9$ mutant protein was less stable than the wild-type protein and it showed an altered subcellular localization in HEK293T and HEI-OC1 cells. Whereas the wild-type proteins were mainly aggregated near the nucleus, the p.Met281Hisfs ${ }^{* 9}$ mutants were more widely distributed throughout the cytoplasm. Furthermore, these authors demonstrated that p.Met281Hisfs ${ }^{* 9}$ showed a decreased ability to oligomerize [19]. It has also been postulated that HOMER2 could play an important role in maintaining stereocilia through its interaction with CDC42 [19], therefore the truncation of HOMER2 in the CBD could eventually prevent its interaction with other HOMER protein family members and with other proteins like CDC42. Indeed, targeted deletion of Cdc42 in murine hair cells causes a progressive hearing loss phenotype that is comparable to the hearing loss phenotype in the Spanish and Chinese families [19]. Another possibility is that the HOMER 2 mutation identified in this study may cause nonsense-mediated decay (NMD), a mechanism that affects the processing of the transcripts at different extent depending on the type of mutation and gene involved as previously reported in other pathologies like Neurofibromatosis I [31]. In this regard, and in contrast to mouse mutants homozygous for the targeted deletion of Homer 2 that display early-onset rapidly progressive hearing loss, mice heterozygous for the targeted deletion of exon 3 in Homer 2 $\left(\mathrm{Homer}^{-/+}\right)$displayed normal hearing levels [18]. It may indicate that a moderate or even low extent NMD might be associated with HOMER2 frameshift mutations thus suggesting that the pathophysiology of the DFNA68 hearing loss in the Spanish and Chinese families would not be mediated by haploinsufficiency, but by a gain-of-function of the $\mathrm{Ct}$ aberrant tail or by a dominant-negative mechanism as it has been postulated for the p.Arg196Pro missense mutation [18]. However, more experiments to detect HOMER2 mutant transcripts levels by using a gene-editing tool to mimic actual mutation in cell lines or the generation of knock-in murine models are necessary to fully understand the underlying mechanism of pathogenesis linked to DFNA68 frameshift mutations.

Regarding the clinical phenotype, the hearing loss observed in HOMER2 patients caused by the missense (p.Arg196Pro) and two truncating mutations seems to be quite similar in the three studied families. Affected individuals show progressive hearing loss affecting mainly the high frequencies (downsloping profile) with a typical onset in the first decade of life (7-9 years old), although a more severe phenotype was detected in patients bearing the truncating mutations when age-matched hearing-impaired subjects of the three families were compared. For individuals in a similar age-range, those carrying the missense p.Arg196Pro mutation [18] displayed minor affectation on the entire range of frequencies (i.e., subject IV:2, 8y.o, IV:10, 15y.o, and III:4, 34y.o, European ascent family) than patients carrying the p.Met281Hisfs*9 (subject IV:7, 7y.o; III:10, 34y.o, and III:8, 39y.o in the Chinese family) or the p.Pro278Alafs*10 variant (subject II:2, 8y.o; II:3, 15y.o, and I:2, 39 y.o in the Spanish family). The presence of tinnitus or cranial tinnitus, however, has only been displayed by some affected members of the Chinese family and this phenotype was 
not present in any of the other two families. The identification of other HOMER2 cases is, therefore, necessary to further establish more accurate genotype-phenotype correlations.

In summary, we have identified a third variant in HOMER2; the first one reported in the Spanish population, thus contributing to expanding the mutational spectrum of this gene in other populations. Our study also highlights the importance of using NGS-based diagnostic methods to identify mutations in low-prevalence deafness genes like HOMER2, thus helping to improve our knowledge about the pathophysiology of DFNA68 and to define more accurate genotype-phenotype correlations in this disorder.

Author Contributions: Conceptualization, M.M. and M.Á.M.-P.; Data curation, M.L., M.V. and I.d.C.; Formal analysis, M.L. and M.M.; Funding acquisition, M.Á.M.-P.; Methodology, M.M.; Supervision, M.Á.M.-P.; Writing—original draft, M.L., M.M. and M.Á.M.-P. All authors have read and agreed to the published version of the manuscript.

Funding: This research was supported by grants from the Spanish Institute of Health Carlos III (ISCIII) cofunded with the European Regional Development Fund (ERDF) within the "Plan Estatal de Investigación Científica y Técnica y de Innovación 2017-2020" (PI14-948, PI17-1659 and PI20/0429 to MAMP), the Spanish Center for Biomedical Network Research on Rare Diseases (CIBERER, 06/07/0036 grant, to MAMP) and by the Regional Government of Madrid (CAM, B2017/ BMD3721 grant to MAMP).

Institutional Review Board Statement: The study was conducted according to the guidelines of the Declaration of Helsinki, and approved by the Institutional Review Board (or Ethics Committee) of Hospital Ramón y Cajal (protocol code 288-17; 29 January 2018).

Informed Consent Statement: Informed consent was obtained from all subjects involved in the study.

Data Availability Statement: The data presented in this study are openly available in ClinVar (accession\# SCV001499845).

Acknowledgments: The authors sincerely thank the family for their participation in this study.

Conflicts of Interest: The authors declare no conflict of interest. The funders had no role in the design of the study; in the collection, analyses, or interpretation of data; in the writing of the manuscript, or in the decision to publish the results.

\section{References}

1. Petit, C.; Levilliers, J.; Hardelin, J.P. Molecular genetics of hearing loss. Annu. Rev. Genet. 2001, 35, 589-646. [CrossRef]

2. Morton, C.C.; Nance, W.E. Newborn hearing screening-a silent revolution. N. Engl. J. Med. 2006, 354, 2151-2164. [CrossRef]

3. Van Camp, G.; Smith, R.J. Hereditary Hearing Loss Homepage. Available online: https://hereditaryhearingloss.org (accessed on 20 December 2020).

4. Hilgert, N.; Smith, R.J.; Van Camp, G. Function and expression pattern of nonsyndromic deafness genes. Curr. Mol. Med. 2009, 9, 546-564. [CrossRef]

5. Mencía, A.; Modamio-Høybjør, S.; Redshaw, N.; Morín, M.; Mayo-Merino, F.; Olavarrieta, L.; Aguirre, L.A.; del Castillo, I.; Steel, K.P.; Dalmay, T.; et al. Mutations in the seed region of human miR-96 are responsible for nonsyndromic progressive hearing loss. Nat. Genet. 2009, 41, 609-613. [CrossRef] [PubMed]

6. Norton, N.; Williams, H.J.; Williams, N.M.; Spurlock, G.; Zammit, S.; Jones, G.; Jones, S.; Owen, R.; O’Donovan, M.C.; Owen, M.J. Mutation screening of the Homer gene family and association analysis in schizophrenia. Am. J. Med. Genet. B Neuropsychiatr. Genet. 2003, 120, 18-21. [CrossRef]

7. Shiraishi-Yamaguchi, Y.; Furuichi, T. The Homer family proteins. Genome Biol. 2007, 8, 206. [CrossRef]

8. Worley, P.F.; Worley, P.F.; Zeng, W.; Huang, G.; Kim, J.Y.; Shin, D.M.; Kim, M.S.; Yuan, J.P.; Kiselyov, K.; Muallem, S. Homer proteins in $\mathrm{Ca}^{2+}$ signaling by excitable and non-excitable cells. Cell Calcium 2007, 42, 363-371. [CrossRef] [PubMed]

9. Yang, Y.M.; Lee, J.; Jo, H.; Park, S.; Chang, I.; Muallem, S.; Shin, D.S. Homer2 protein regulates plasma membrane Ca ${ }^{2+}$-ATPasemediated $\mathrm{Ca}^{2+}$ signaling in mouse parotid gland acinar cells. J. Biol. Chem. 2014, 289, 24971-24979. [CrossRef] [PubMed]

10. Jardin, I.; López, J.J.; Berna-Erro, A.; Salido, G.M.; Rosado, J.A. Homer proteins in Ca ${ }^{2+}$ entry. IUBMB Life 2013, 65, 497-504. [CrossRef] [PubMed]

11. Tao-Cheng, J.H.; Thein, S.; Yang, Y.; Reese, T.S.; Gallant, P.E. Homer is concentrated at the postsynaptic density and does not redistribute after acute synaptic stimulation. Neuroscience 2014, 266, 80-90. [CrossRef]

12. Kato, A.; Ozawa, F.; Saitoh, Y.; Fukazawa, Y.; Sugiyama, H.; Inokuchi, K. Novel members of the Vesl/Homer family of PDZ proteins that bind metabotropic glutamate receptors. J. Biol. Chem. 1998, 273, 23969-23975. [CrossRef] [PubMed] 
13. Barzik, M.; Carl, U.D.; Schubert, W.D.; Frank, R.; Wehland, J.; Heinz, D.W. The N-terminal domain of Homer/Vesl is a new class II EVH1 domain. J. Mol. Biol. 2001, 309, 155-169. [CrossRef] [PubMed]

14. Sun, J.; Tadokoro, S.; Imanaka, T.; Murakami, S.D.; Nakamura, M.; Kashiwada, K.; Ko, J.; Nishida, W.; Sobue, K. Isolation of PSD-Zip45, a novel Homer/vesl family protein containing leucine zipper motifs, from rat brain. FEBS Lett. 1998, 437, 304-308. [CrossRef]

15. Shiraishi, Y.; Mizutani, A.; Bito, H.; Fujisawa, K.; Narumiya, S.; Mikoshiba, K.; Furuichi, T. Cupidin, an isoform of Homer/Vesl, interacts with the actin cytoskeleton and activated rho family small GTPases and is expressed in developing mouse cerebellar granule cells. J. Neurosci. 1999, 19, 8389-8400. [CrossRef] [PubMed]

16. Shiraishi, Y.; Mizutani, A.; Yuasa, S.; Mikoshiba, K.; Furuichi, T. Differential expression of Homer family proteins in the developing mouse brain. J. Comp. Neurol. 2004, 473, 582-599. [CrossRef] [PubMed]

17. Reibring, C.G.; Hallberg, K.; Linde, A.; Gritli-Linde, A.G. Distinct and Overlapping Expression Patterns of the Homer Family of Scaffolding Proteins and Their Encoding Genes in Developing Murine Cephalic Tissues. Int. J. Mol. Sci. 2020, 21, 1264. [CrossRef]

18. Azaiez, H.; Decker, A.R.; Booth, K.T.; Simpson, A.C.; Shearer, A.E.; Huygen, P.L.M.; Bu, F.; Hildebrand, M.S.; Ranum, P.T.; Shibata, S.B.; et al. HOMER2, a stereociliary scaffolding protein, is essential for normal hearing in humans and mice. PLoS Genet. 2015, 11, e1005137. [CrossRef] [PubMed]

19. Lu, X.; Wang, Q.; Gu, H.; Zhang, X.; Qi, Y.; Liu, Y. Whole exome sequencing identified a second pathogenic variant in HOMER2 for autosomal dominant nonsyndromic deafness. Clin. Genet. 2018, 94, 419-428. [CrossRef]

20. Morín, M.; Borreguero, L.; Booth, K.T.; Lachgar, M.; Huygen, P.; Villamar, M.; Mayo, F.; Barrio, L.C.; Santos Serrão de Castro, L.; Morales, M.; et al. Insights into the pathophysiology of DFNA10 hearing loss associated with novel EYA4 variants. Sci. Rep. 2020, 10, 6213. [CrossRef]

21. Shiraishi, Y.; Sato, Y.; Sakai, R.; Mizutani, A.; Knöpfel, T.; Mori, N.; Mikoshiba, K.; Furuichi, T. Interaction of Cupidin/Homer2 with two actin cytoskeletal regulators, Cdc42 small GTPase and Drebrin, in dendritic spines. BMC Neurosci. $2009,10,25$.

22. Richards, S.; Aziz, N.; Bale, S.; Bick, D.; Das, S.; Gastier-Foster, J.; Grody, W.W.; Hegde, M.; Lyon, E.; Spector, E.; et al. Standards and guidelines for the interpretation of sequence variants: A joint consensus recommendation of the American College of Medical Genetics and Genomics and the Association for Molecular Pathology. Genet. Med. 2015, 17, 405-424. [CrossRef] [PubMed]

23. Kopanos, C.; Tsiolkas, V.; Kouris, A.; Chapple, C.E.; Albarca Aguilera, M.; Meyer, R.; Massouras, A. VarSome: The human genomic variant search engine. Bioinformatics 2019, 35, 1978-1980. [CrossRef]

24. Karczewski, K.J.; Francioli, L.C.; Tiao, G.; Cummings, B.B.; Alföldi, J.; Wang, Q.; Collins, R.L.; Laricchia, K.M.; Ganna, A.; Birnbaum, D.P.; et al. The mutational constraint spectrum quantified from variation in 141,456 humans. Nature 2020, 581, 434-443. [CrossRef]

25. Peña-Chilet, M.; Roldán, G.; Perez-Florido, J.; Ortuño, J.M.; Carmona, R.; Aquino, V.; Lopez-Lopez, D.; Loucera, C.; Fernandez-Rueda, J.L.; Gallego, A.; et al. CSVS, a crowdsourcing database of the Spanish population genetic variability. Nucleic Acid Res. 2020, 49, D1130-D1137. [CrossRef] [PubMed]

26. Azaiez, H.; Booth, K.T.; Ephraim, S.S.; Crone, B.; Black-Ziegelbein, E.A.; Marini, R.J.; Shearer, A.E.; Sloan-Heggen, C.M.; Kolbe, D.; Casavant, T.; et al. Genomic Landscape and Mutational Signatures of Deafness-Associated Genes. Am. J. Hum. Genet. 2018, 103, 484-497. [CrossRef]

27. Deafness Variation Database. Available online: http:/ / deafnessvariationdatabase.org/ (accessed on 20 December 2020).

28. Ueyama, T.; Sakaguchi, H.; Nakamura, T.; Goto, A.; Morioka, S.; Shimizu, A.; Nakao, K.; Hishikawa, Y.; Ninoyu, Y.; Kassai, H.; et al. Maintenance of stereocilia and apical junctional complexes by Cdc42 in cochlear hair cells. J. Cell. Sci. 2014, 127, $2040-2052$. [CrossRef] [PubMed]

29. Kirjavainen, A.; Laos, M.; Anttonen, T.; Pirvola, U. The Rho GTPase Cdc42 regulates hair cell planar polarity and cellular patterning in the developing cochlea. Biol. Open 2015, 4, 516-526. [CrossRef]

30. Wildeman, M.; Ophuizen, E.V.; den Dunnen, J.T.; Taschner, P.E.M. Improving sequence variant descriptions in mutation databases and literature using the Mutalyzer sequence variation nomenclature checker. Hum. Mutat. 2008, 29, 6-13. [CrossRef] [PubMed]

31. Pros, E.; Larriba, S.; López, E.; Ravella, A.; Gili, M.L.; Kruyer, H.; Valls, J.; Serra, E.; Lázaro, C. NF1 mutation rather than individual genetic variability is the main determinant of the NF1-transcriptional profile of mutations affecting splicing. Hum. Mutat. 2006, 27, 1104-1114. [CrossRef] 